Technical Note

\title{
Critical Metal Particles in Copper Sulfides from the Supergiant Río Blanco Porphyry Cu-Mo Deposit, Chile
}

\author{
Jorge Crespo ${ }^{1,2, * \mathbb{C}}$, Martin Reich ${ }^{1,2} \mathbb{D}$, Fernando Barra ${ }^{1,2}$, Juan José Verdugo ${ }^{3}$ and \\ Claudio Martínez ${ }^{3}$ \\ 1 Department of Geology and Andean Geothermal Center of Excellence (CEGA), Facultad de Ciencias Físicas \\ y Matemáticas, Universidad de Chile, Plaza Ercilla 803, Santiago 8370450, Chile; mreich@cec.uchile.cl (M.R.); \\ fbarrapantoja@ing.uchile.cl (F.B.) \\ 2 Millennium Nucleus for Metal Tracing Along Subduction, Facultad de Ciencias Físicas y Matemáticas, \\ Universidad de Chile, Santiago 8370450, Chile \\ 3 Codelco División Andina, Avenida Santa Teresa, N 513 Los Andes, V Región 2102660, Chile; \\ jverdugo@codelco.cl (J.J.V.); cmart006@codelco.cl (C.M.) \\ * Correspondence: jorge.crespo@ug.uchile.cl; Tel.: +56-9-8978-3139
}

Received: 14 October 2018; Accepted: 6 November 2018; Published: 9 November 2018

\begin{abstract}
Porphyry copper-molybdenum deposits (PCDs) are the world's most important source of copper, molybdenum and rhenium. Previous studies have reported that some PCDs can have sub-economic to economic grades of critical metals, i.e., those elements that are both essential for modern societies and subject to the risk of supply restriction (e.g., platinum group elements (PGE), rare earth elements (REE), In, $\mathrm{Co}, \mathrm{Te}, \mathrm{Ge}, \mathrm{Ga}$, among others). Even though some studies have reported measured concentrations of Pd and Pt in PCDs, their occurrence and mineralogical forms remain poorly constrained. Furthermore, these reconnaissance studies have focused predominantly on porphyry $\mathrm{Cu}-\mathrm{Au}$ deposits, but very limited information is available for porphyry $\mathrm{Cu}-\mathrm{Mo}$ systems. In this contribution, we report the occurrence of critical metal ( $\mathrm{Pd}, \mathrm{Pt}, \mathrm{Au}, \mathrm{Ag}$, and $\mathrm{Te}$ ) inclusions in copper sulfides from one of the largest PCDs in the world, the supergiant Río Blanco-Los Bronces deposit in central Chile. Field emission scanning electron microscope (FESEM) observations of chalcopyrite and bornite from the potassic alteration zone reveal the presence of micro- to nano-sized particles $(<1-10 \mu \mathrm{m})$ containing noble metals, most notably $\mathrm{Pd}, \mathrm{Au}$, and Ag. The mineralogical data show that these inclusions are mostly tellurides, such as merenskyite $\left((\mathrm{Pd}, \mathrm{Pt})(\mathrm{Bi}, \mathrm{Te})_{2}\right), \mathrm{Pd}$-rich hessite $\left(\mathrm{Ag}_{2} \mathrm{Te}\right)$, sylvanite $\left((\mathrm{Ag}, \mathrm{Au}) \mathrm{Te}_{2}\right)$ and petzite $\left(\mathrm{Ag}_{3} \mathrm{AuTe}_{2}\right)$. The data point to $\mathrm{Pd}$ (and probably $\mathrm{Pt})$ partitioning in copper sulfides during the high-temperature potassic alteration stage, opening new avenues of research aimed at investigating not only the mobility of PGE during mineralization and partitioning into sulfides, but also at exploring the occurrence of critical metals in porphyry $\mathrm{Cu}-\mathrm{Mo}$ deposits.
\end{abstract}

Keywords: platinum-group elements; silver; gold; Pd-tellurides; porphyry $\mathrm{Cu}-\mathrm{Mo}$; Rio Blanco-Los Bronces; Chile

\section{Introduction}

Porphyry $\mathrm{Cu}-\mathrm{Mo}$ deposits (PCDs) are typically associated with calc-alkaline intrusive rocks, and currently provide $60 \%$ of world's copper supply [1]. In addition to $\mathrm{Cu}$, PCDs are major sources of Mo and Re [2], and previous studies have reported the presence of relevant amounts of other metals including $\mathrm{Au}, \mathrm{Ag}, \mathrm{Se}, \mathrm{Te}, \mathrm{U}, \mathrm{W}, \mathrm{Bi}, \mathrm{Co}$, and platinum group elements (PGE) [3-11]. Some of these elements are considered as "critical" for the expected growth of renewable energy technology, and thus, 
they are both essential for modern societies and subject to the risk of supply restriction [12-14]. Despite their strategic importance, surprisingly few trace element concentration data are available for sulfides in PCDs when compared to other deposits such as orogenic, epithermal, Carlin-type Au deposits, and volcanogenic massive sulfide (VMS) deposits [15-18]. Only a small number of studies have constrained the concentrations of trace metals in sulfides from PCDs using modern micro-analytical techniques (e.g., [7,19-23]); hence, many questions still remain concerning the speciation and mineralogical form of trace metals within sulfides.

Among trace metals, gold and silver are relevant byproducts in porphyry $\mathrm{Cu}-\mathrm{Mo}$ deposits, with estimated median grades of $9 \mathrm{ppb} \mathrm{Au}$ and $\sim 1 \mathrm{ppm} \mathrm{Ag}$ [24]. Previous studies have shown that Au is preferentially incorporated into bornite and chalcopyrite within potassic alteration zones, with concentrations reaching $\sim 2-4 \mathrm{ppm}$ in chalcopyrite and $\sim 80-364 \mathrm{ppm}$ in bornite $[7,25]$. Silver, on the other hand, has been reported to reach up to hundreds or thousands of ppm in bornite, chalcopyrite, and chalcocite in porphyry-type deposits in northern Chile [26,27]. A recent study in PCDs from Romania shows that Ag in bornite is an order of magnitude greater than in chalcopyrite, and two orders of magnitude higher than in pyrite [20].

Anomalous PGE concentrations have been documented in a number of PCDs worldwide. Tarkian et al., 1999 [4] reported PGE data from sulfide, and flotation concentrates from 33 PCDs from Chile, Peru, Argentina, US, Canada, Indonesia, and Papua New Guinea. The cited study reveals that PCDs can contain relatively high Pd concentrations (130-1900 ppb) that are correlated with high Au contents (1-28 ppm). Tarkian et al., 1999 [4] also identified the presence of platinum group minerals (PGM), which occurred as micrometer-scale inclusions in chalcopyrite. Pašava et al., 2010 [9] reported an average Pd value of $55.2 \mathrm{ppb}$ in flotation concentrates from the Kalmakyr porphyry $\mathrm{Cu}-\mathrm{Au}-\mathrm{Mo}$ deposit in Uzbekistan and where the concentration of $\mathrm{Pd}$ and $\mathrm{Au}$ show a strong correspondence with copper. Palladium was also found associated with $\mathrm{Ag}$, Se, and $\mathrm{S}$ in two alkaline porphyry $\mathrm{Cu}-\mathrm{Au}$ deposits (the Afton and Mount Milligan deposits) in the Canadian Cordillera [28]. The cited authors documented that at least $90 \%$ of the bulk Pd + Pt occurs within pyrite, and it is not related to copper sulfides. Both Pd and Pt are highly enriched in the cores of the pyrite grains (up to $90 \mathrm{ppm}$ and $20 \mathrm{ppm}$, respectively) and their abundance correlates well with the Co content in pyrite (up to $4 \mathrm{wt} \%$ ). These large concentrations of trace metals have not been observed directly in porphyry $\mathrm{Cu}-\mathrm{Mo}$ deposits, an attribute that has led to overlooking their PGE potential.

Here, we document that the occurrence of noble metal ( $\mathrm{Au}, \mathrm{Ag}$, and $\mathrm{Pd}$ )-bearing mineral inclusions in copper sulfides within the potassic alteration zone of the world-class Río Blanco porphyry $\mathrm{Cu}-\mathrm{Mo}$ deposit in central Chile. We combined observations using field emission scanning electron microscopy (FESEM) and electron microprobe analyses (EMPA) of selected grains of chalcopyrite and bornite. Our results show that PGE minerals may be more frequent in PCDs than previously thought, and that high-resolution FESEM techniques greatly facilitate the imaging and characterization of micrometer to nanometer-sized particles in copper sulfides.

\section{Geology of the Río Blanco Deposit}

The Río Blanco PCD is located $\sim 60 \mathrm{~km}$ northeast of Santiago, at an altitude of between 3700 and $4300 \mathrm{~m}$ above sea level in the high Andes of Central Chile (Figure 1A). From north to south, mining activities are focused on three areas, i.e., the Río Blanco (RB) underground mine, and the Don Luis (DL) and Sur-Sur (SS) open pits (Figure 1B). In 2017, the mine produced 220,000 tons of fine copper. 


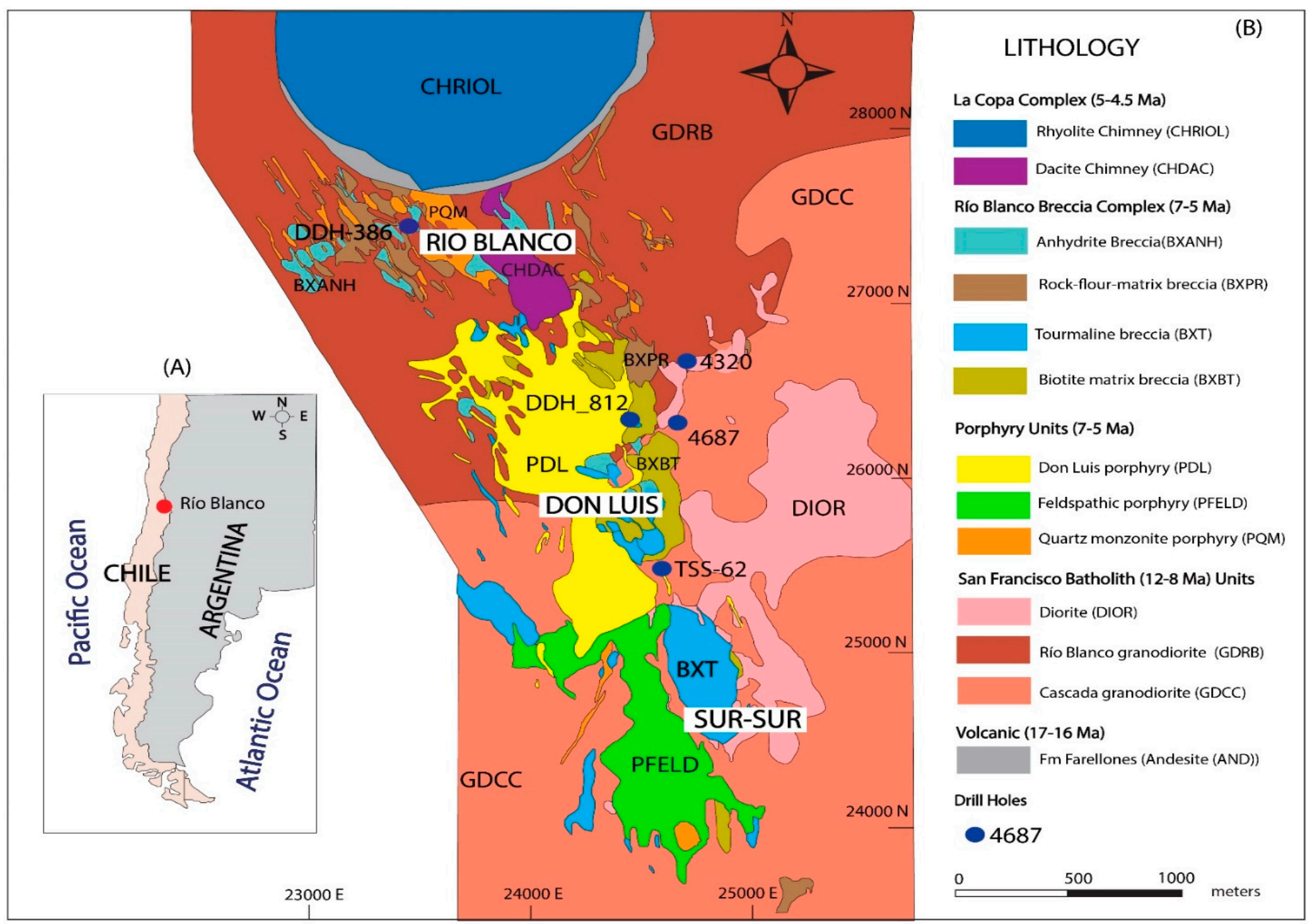

Figure 1. (A) Location of the Río Blanco porphyry Cu-Mo deposit in Central Chile. (B) Geology of the Río Blanco PCD, modified after Ferraz and Cruz 2011 [29]. 
The oldest rocks in the Río Blanco PCD correspond to andesite lavas and stratified basaltic andesites of the Farellones Formation [30], with reported U-Pb zircon ages of $17.2 \pm 0.05 \mathrm{Ma}$ [31] (Figure 1B). The Farellones Formation is intruded by the San Francisco Batholith (SFB), which comprises granodiorites, monzodiorites, and tonalites [32,33]. The SFB comprises several magmatic pulses, including the Río Blanco granodiorite (GDRB) and the Cascada granodiorite (GDCC), with reported $\mathrm{U}-\mathrm{Pb}$ zircon ages of $11.96 \pm 0.04 \mathrm{Ma}$ and $8.4 \pm 0.23 \mathrm{Ma}$, respectively [31].

The SFB is cut by porphyries of quartz monzonitic (PQM) and feldspathic (PFELD) compositions, with reported U-Pb zircon ages of $6.32 \pm 0.09 \mathrm{Ma}$ and $5.84 \pm 0.03 \mathrm{Ma}$, respectively [31] (Figure 1B). Several hydrothermal breccia types are recognized in Río Blanco: igneous, igneous/hydrothermal, hydrothermal (biotite and tourmaline bearing), and rock-flour breccias [34]. The hydrothermal breccias are closely related to the porphyry units and the bulk of the copper sulfide mineralization occurs as cement in these breccias. The Don Luis porphyry (PDL) crosscuts the mineralized breccia complex and corresponds to a subvertical intrusion of dacitic composition ( $\mathrm{U}-\mathrm{Pb}$ zircon age of $5.23 \pm 0.07 \mathrm{Ma}$ [31]). The youngest unit in the district corresponds to the La Copa Volcanic Complex (CVLC), which is located in the northern part of the deposit. The CVLC comprises crystalline tuffs (CHDAC, Dacitic chimney; $\mathrm{U}-\mathrm{Pb}$ zircon age of $4.57 \pm 0.08 \mathrm{Ma}$ ) and lithic tuffs (CHRIOL, Rhyolitic chimney; $\mathrm{U}-\mathrm{Pb}$ zircon age of $4.31 \pm 0.05 \mathrm{Ma}$ ) [34]. Magmatic and hydrothermal fluid flow was channeled and focused by both sets of preexisting oblique structures (NE and NW-striking faults) and, in turn, fault rupture was driven by high fluid pressures [35].

Hydrothermal alteration at the Río Blanco PCD is characterized by a propylitic (chlorite-epidote) alteration that grades to biotite-chlorite and biotite towards the innermost part of the deposit. Potassic alteration is related to the porphyry phases, and it is characterized by a high content of biotite + potassium feldspar \pm albite, and lower contents of anhydrite. Potassic alteration occurs at depth, with chalcopyrite \pm bornite \pm molybdenite and minor pyrite. This early alteration is identified by three types of veinlets: (i) Early Biotite Transitional (EBT) veins characterized by quartz + chalcopyrite \pm bornite $\pm \mathrm{K}$ feldspar \pm anhydrite with biotite haloes; (ii) sinuous, A-type veinlets with quartz $\pm \mathrm{K}$ feldspar \pm chalcopyrite; and (iii) thicker, B-type veinlets with quartz \pm molybdenite. The phyllic stage, overimposed on the potassic alteration event, is defined by the development of C-type gray-green sericite (GGS) veinlets with quartz + chalcopyrite, and a halo with phengite-celadonite $\pm \mathrm{K}$ feldspar and abundant chalcopyrite \pm bornite \pm pyrite. This GGS alteration varies from strong to moderate to weak from the center to the outer zones of the deposit. In the shallowest parts of the deposit, a late-stage alteration event is recognized by the presence of D-type quartz-sericite veinlets (QS), composed of quartz + pyrite \pm chalcopyrite and sericite \pm clays (illite-kaolinite) halos with pyrite $>$ chalcopyrite [36]. Late E-type veinlets are composed of quartz + carbonates (siderite-ankerite) + pyrite \pm gypsum \pm sphalerite \pm tennantite \pm enargite-luzonite \pm galena \pm bornite, with a sericite + clays halo.

\section{Samples and Methods}

CODELCO-Andina has a multi-element (51 elements) inductively coupled plasma mass spectrometry (ICP-MS) geochemical database of 10,140 samples (whole rock) from drill holes. A total of 28 core-samples from six drill holes that cross-cut the main mineralization-alteration zones at the Río Blanco deposit were collected for this exploratory study of sulfides. The samples were selected based on their Ag, Bi, and Te contents, with a focus on high grade material ( $>3 \mathrm{ppm} \mathrm{Ag}, 1.32 \mathrm{ppm}$ $\mathrm{Bi}$, and $0.24 \mathrm{ppm} \mathrm{Te}$ ). The sulfide minerals studied here included chalcopyrite and bornite from the potassic alteration zone. Polished thick sections were inspected for the presence of micro- to nanometer-sized inclusions using a combination of conventional and field-emission scanning electron microscopy techniques. The SEM observations were carried out at the Andean Geothermal Center of Excellence (CEGA), Universidad de Chile, Santiago, Chile, using a FEI Quanta 250 SEM (Thermo Fisher Scientific) equipped with a secondary electron (SE) and backscattered electron (BSE) detectors, and an energy-dispersive X-ray spectrometer (EDS). The analytical parameters were: accelerating voltage of 
$15-20 \mathrm{kV}$ and an emission current of $\sim 80 \mu \mathrm{A}$, takeoff angle $\sim 35^{\circ}$, spot beam was $4-5 \mu \mathrm{m}$ in diameter, and a working distance of $\sim 10 \mathrm{~mm}$. Semi-quantitative EDS analyses were used to identify major elements in individual mineral phases. High-resolution imaging of micro- to nano-sized inclusions was achieved using field-emission scanning electron microscopy (FESEM). Observations were performed using a FEI Quanta 250 FEG at the Center for Research in Nanotechnology and Advanced Materials (CIEN) at the Pontificia Universidad Católica de Chile, Santiago, Chile. The FESEM is equipped with in-olumn detector (ICD) for SE and BSE, and an EDS detector. Operating conditions included an accelerating voltage of $20 \mathrm{kV}$, spot beam was $\sim 4 \mu \mathrm{m}$ in diameter, takeoff angle $\sim 35^{\circ}-37^{\circ}$, and the live time was $45 \mathrm{~s}$ and a working distance of $\sim 10 \mathrm{~mm}$.

In addition, major and minor element contents in chalcopyrite and bornite, and one palladium telluride inclusion were determined by EMPA using a JEOL JXA-8230 Superprobe at the LAMARX Laboratory of the Universidad Nacional de Córdoba, Argentina. Elements and X-ray lines used for the analysis were $\mathrm{Hg}(\mathrm{M} \alpha)$, Te $(\mathrm{L} \alpha)$, Se $(\mathrm{L} \alpha), \mathrm{Bi}(\mathrm{M} \alpha), \mathrm{Au}(\mathrm{M} \alpha), \mathrm{S}(\mathrm{K} \alpha)$, $\mathrm{Fe}(\mathrm{K} \alpha), \mathrm{Co}(\mathrm{K} \alpha), \mathrm{Zn}(\mathrm{K} \alpha)$, As $(\mathrm{K} \alpha)$, $\mathrm{Ag}(\mathrm{L} \alpha), \mathrm{Pb}(\mathrm{M} \beta), \mathrm{Sb}(\mathrm{L} \alpha), \mathrm{Cu}(\mathrm{K} \alpha), \mathrm{Ni}(\mathrm{K} \alpha), \operatorname{Mn}(\mathrm{K} \alpha), \operatorname{Pt}(\mathrm{M} \alpha), \operatorname{Re}(\mathrm{M} \alpha), \operatorname{Pd}(\mathrm{L} \alpha), \operatorname{Rh}(\mathrm{L} \alpha), \operatorname{Ru}(\mathrm{L} \alpha)$, $\operatorname{Ir}(\mathrm{M} \alpha)$, Os $(\mathrm{M} \alpha)$. Operating conditions included an accelerating voltage of $20 \mathrm{kV}$ and a beam current of $20 \mathrm{nA}$, and the electron beam was $\sim 1 \mu \mathrm{m}$ in diameter. The counting time was $40 \mathrm{~s}$ for $\mathrm{Hg}, \mathrm{Te}, \mathrm{Se}, \mathrm{Bi}$, $\mathrm{Au}, \mathrm{S}, \mathrm{Fe}, \mathrm{Co}, \mathrm{Zn}, \mathrm{As}, \mathrm{Ag}, \mathrm{Pb}, \mathrm{Sb}, \mathrm{Cu}, \mathrm{Ni}$, and $\mathrm{Mn}$. The counting time was $20 \mathrm{~s}$ for $\mathrm{Pt}, \mathrm{Re}, \mathrm{Pd}, \mathrm{Rh}, \mathrm{Ru}$, $\mathrm{Ir}$, and Os. Standard specimens used for calibration were $\mathrm{HgTe}$ (for $\mathrm{Hg}$ and Te), NiSe (for Ni and Se), $\mathrm{Bi}_{2} \mathrm{~S}_{3}$ (for $\mathrm{Bi}$ ), $\mathrm{Au}^{0}$ (for $\mathrm{Au}$ ), $\mathrm{CuFeS}_{2}$ (for $\mathrm{Cu}, \mathrm{Fe}$ and $\mathrm{S}$ ), $\mathrm{CoAs}_{3}$ (for $\mathrm{Co}$ ), $\mathrm{ZnS}$ (for $\mathrm{Zn}$ ), NiAs (for As), $\mathrm{Ag}^{0}$ (for $\mathrm{Ag}$ ), $\mathrm{PbS}$ (for $\mathrm{Pb}$ ), $\mathrm{Sb}_{2} \mathrm{~S}_{3}$ (for $\mathrm{Sb}$ ), $\mathrm{Mn}^{0}$ (for $\mathrm{Mn}$ ), $\mathrm{Pt}^{0}$ (for $\mathrm{Pt}$ ), $\mathrm{Re}^{0}$ (for $\mathrm{Re}$ ), $\mathrm{Pd}^{0}$ (for $\mathrm{Pd}$ ), $\mathrm{Rh}^{0}$ (for $\mathrm{Rh}), \mathrm{Ru}^{0}$ (for $\mathrm{Ru}$ ), $\mathrm{Ir}^{0}$ (for Ir), and $\mathrm{Os}^{0}$ (for Os).

\section{Results}

Representative EMPA analyses in chalcopyrite and bornite from the potassic alteration zone are reported in Table 1. Contents of $\mathrm{Cu}, \mathrm{Fe}$, and $\mathrm{S}$ in chalcopyrite ranged between 35.17 to $35.69 \mathrm{wt} \%$, 29.10 to $29.88 \mathrm{wt} \%$, and 34.09 to $34.46 \mathrm{wt} \%$ respectively. EMPA-WDS analyses showed that chalcopyrite contained $\mathrm{Ag}<0.04 \mathrm{wt} \%, \mathrm{Au}<0.08 \mathrm{wt} \%$, Co $<0.06 \mathrm{wt} \%, \mathrm{Ni}<0.01 \mathrm{wt} \%, \mathrm{Bi}<0.07 \mathrm{wt} \%$, $\mathrm{Hg}<0.12 \mathrm{wt} \%$, Te $<0.03 \mathrm{wt} \%$, Se $<0.03 \mathrm{wt} \%$, As $<0.06 \mathrm{wt} \%$, and $\mathrm{Pb}<0.07 \mathrm{wt} \%$. EMPA-WDS analyses of bornite ranged from 62.47 to $63.90 \mathrm{wt} \% \mathrm{Cu}, 10.99$ to $11.62 \mathrm{wt} \% \mathrm{Fe}$, and 25.48 to $26.02 \mathrm{wt} \% \mathrm{~S}$. Other elements detected in bornite included $\mathrm{Au}<0.05 \mathrm{wt} \%, \mathrm{Ag}<0.14 \mathrm{wt} \%$, Bi $<0.07 \mathrm{wt} \%$, $\mathrm{Hg}<0.10 \mathrm{wt} \%, \mathrm{Te}<0.03 \mathrm{wt} \%$, Se $<0.02 \mathrm{wt} \%$, As $<0.13 \mathrm{wt} \%, \mathrm{~Pb}<0.07 \mathrm{wt} \%$, Co $<0.02 \mathrm{wt} \%$, and $\mathrm{Ni}<0.01 \mathrm{wt} \%$. 
Table 1. Summary of representative electron microprobe analyses (EMPA) of chalcopyrite and bornite from the Rio Blanco deposit in (wt $\%$ ). mdl = Minimum detection limits in wt \%. b.d = below detection.

\begin{tabular}{|c|c|c|c|c|c|c|c|c|c|c|c|c|c|c|c|c|c|}
\hline Element & $\mathrm{Cu}$ & $\mathrm{Fe}$ & $\mathbf{S}$ & Au & Ag & $\mathbf{B i}$ & $\mathrm{Hg}$ & $\mathrm{Te}$ & Se & Zn & As & $\mathrm{Pb}$ & $\mathrm{Sb}$ & Co & $\mathbf{N i}$ & Total & \\
\hline mdl & 0.01 & 0.01 & 0.01 & 0.02 & 0.01 & 0.03 & 0.03 & 0.01 & 0.01 & 0.01 & 0.02 & 0.02 & 0.01 & 0.02 & 0.01 & & \\
\hline \multicolumn{18}{|l|}{ Sample DDH386-564 } \\
\hline C1-Сру2 & 35.32 & 29.10 & 34.11 & b.d & b.d & b.d & 0.10 & 0.03 & b.d & b.d & 0.02 & 0.05 & b.d & b.d & b.d & 98.78 & \\
\hline C1-Сру3 & 35.17 & 29.42 & 34.09 & b.d & b.d & b.d & b.d & 0.03 & b.d & b.d & b.d & 0.03 & b.d & 0.04 & b.d & 98.78 & \\
\hline C4-Сpy10 & 35.24 & 29.43 & 34.33 & b.d & b.d & 0.06 & b.d & b.d & b.d & b.d & b.d & b.d & b.d & b.d & b.d & 99.07 & \\
\hline C4-Сpy11 & 35.31 & 29.32 & 34.26 & 0.08 & b.d & b.d & b.d & b.d & 0.02 & b.d & b.d & b.d & b.d & 0.04 & 0.01 & 99.05 & \\
\hline C4-Сpy12 & 35.38 & 29.42 & 34.46 & b.d & b.d & b.d & 0.12 & b.d & 0.02 & b.d & b.d & 0.07 & b.d & b.d & b.d & 99.49 & \\
\hline C3-Сpy13 & 35.55 & 29.88 & 34.26 & b.d & 0.04 & 0.07 & 0.03 & 0.02 & 0.03 & b.d & 0.03 & 0.03 & b.d & 0.06 & b.d & 100.00 & \\
\hline C4-Bn8 & 63.85 & 10.99 & 25.55 & b.d & 0.14 & b.d & 0.10 & b.d & b.d & b.d & b.d & b.d & b.d & 0.02 & b.d & 100.65 & \\
\hline C4-Bn9 & 63.90 & 11.09 & 25.48 & b.d & 0.13 & b.d & 0.05 & 0.03 & b.d & b.d & 0.04 & b.d & b.d & b.d & b.d & 100.74 & \\
\hline C3-Bn15 & 62.67 & 11.62 & 25.76 & b.d & 0.04 & 0.06 & b.d & b.d & b.d & b.d & 0.08 & 0.07 & b.d & b.d & b.d & 100.30 & \\
\hline C3-Bn16 & 62.88 & 11.27 & 25.93 & b.d & 0.06 & b.d & 0.09 & b.d & 0.02 & b.d & 0.13 & b.d & b.d & 0.02 & 0.01 & 100.42 & \\
\hline C3-Bn17 & 62.47 & 11.28 & 26.02 & 0.05 & 0.06 & 0.07 & 0.10 & b.d & b.d & b.d & 0.12 & b.d & b.d & 0.02 & b.d & 100.22 & \\
\hline Element & $\mathrm{Cu}$ & Fe & S & $\mathrm{Au}$ & Ag & $\mathbf{B i}$ & Te & Pd & $\mathbf{P t}$ & $\operatorname{Re}$ & As & Rh & $\mathbf{R u}$ & Ir & Os & $\mathbf{N i}$ & Total \\
\hline mdl & 0.01 & 0.01 & 0.01 & 0.02 & 0.01 & 0.06 & 0.03 & 0.03 & 0.04 & 0.03 & 0.02 & 0.02 & 0.02 & 0.03 & 0.03 & 0.02 & \\
\hline
\end{tabular}


Detailed FESEM inspection of Ag-bearing chalcopyrite and bornite grains revealed the presence of micrometer to nanometer-sized mineral inclusions (Figures 2 and 3).
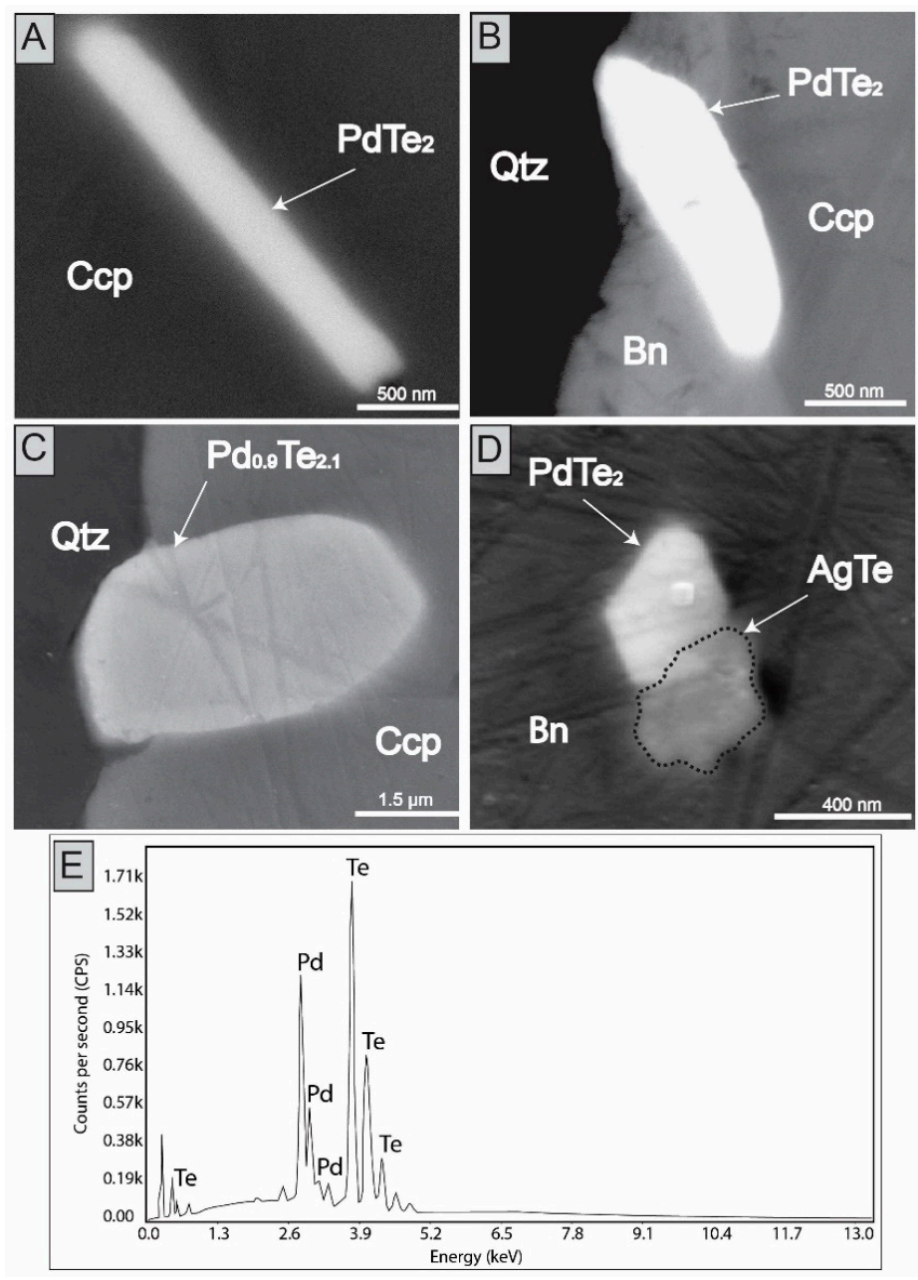

Figure 2. Field-emission scanning electron microscopy (FESEM) images of platinum group minerals (PGM) in chalcopyrite and bornite from Río Blanco. Palladium tellurides are shown in images (A-D). Images (A,B) were taken using the back-scattered electron detector (BSE), while images (C,D) were taken using the secondary electron (SE) detector. (E) shows the energy-dispersive $X$-ray spectrometer (EDS) spectrum of the Pd telluride grain in image (C). Ccp: chalcopyrite, Bn: bornite, Qtz: quartz, AgTe: silver telluride, $\mathrm{PdTe}_{2}$ : merenskyite.

The inclusions occur usually along grain boundaries (Figure 2B) and their morphologies varied from subhedral to tabular, with sizes ranging from $\sim 400 \mathrm{~nm}$ to $\sim 4 \mu \mathrm{m}$. Due to the sub-micrometer size of most inclusions, chemical characterization was carried out semi-quantitatively by means of FESEM-EDS. In most grains, $\mathrm{Pd}$ and Te were detected along with $\mathrm{Cu}, \mathrm{Fe}$, and $\mathrm{S}$ from the sulfide host matrix (Figure 2A,B,D). One quantitative EMPA-WDS spot analysis of a micrometer-sized inclusion (Figure 2C) showed $\sim 23.7 \mathrm{wt} \% \mathrm{Pd}$ and $65.3 \mathrm{wt} \%$ Te (Table 1). Despite the low total ( 97 wt \%), the stoichiometry is consistent with the mineral merenskyite $\left((\mathrm{Pd}, \mathrm{Pt})(\mathrm{Bi}, \mathrm{Te})_{2}\right)$. EMPA-WDS analysis of the same grain (Figure 2C) indicated the presence of $\mathrm{Pt}(1.3 \mathrm{wt} \%), \mathrm{Au}(0.1 \mathrm{wt} \%), \mathrm{Os}(0.1 \mathrm{wt} \%)$ and Bi $(0.4 \mathrm{wt} \%)$. FESEM-EDS analyses of the other Pd-Te-bearing grains shown in Figure 2 were broadly consistent with merenskyite.

Mineral inclusions containing $\mathrm{Au}, \mathrm{Ag}, \mathrm{Hg}$, and Te are shown in Figure 3. Most of these inclusions had anhedral to subhedral forms, some with rectangular and tabular/elongated shapes, and they occurred along grain boundaries (Figure 3A). Semi-quantitative FESEM-EDS analysis indicated that 
the inclusions were most likely electrum $(\mathrm{Au}, \mathrm{Ag} \pm \mathrm{Hg}$ ) (Figure 3A-D), and Au-Ag-Te minerals such as petzite $\left(\mathrm{Au}_{3} \mathrm{AgTe}\right)$ (Figure 3B).
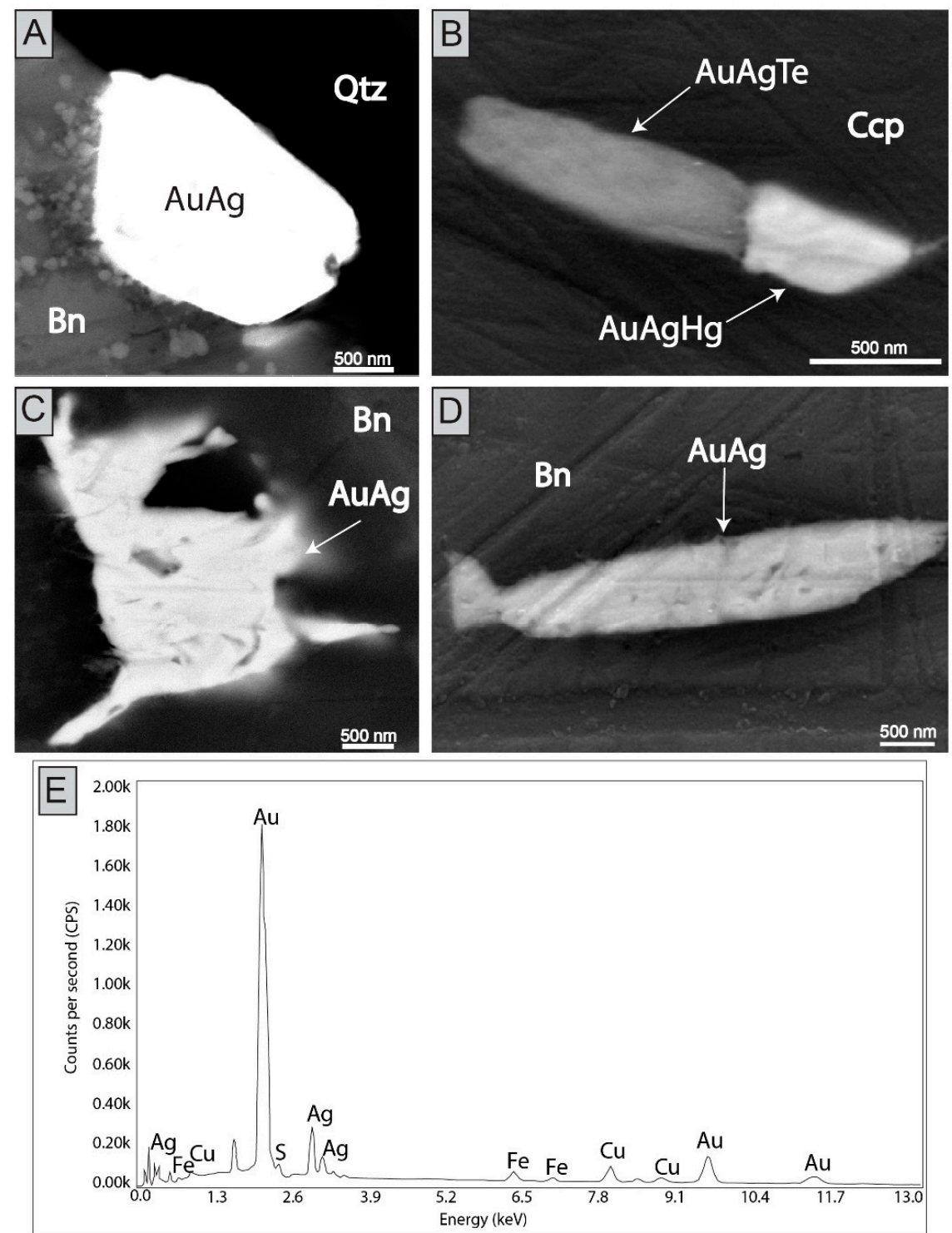

Figure 3. Field-emission scanning electron microscopy (FESEM) images of silver, gold, mercury, and tellurium mineral inclusions in chalcopyrite and bornite from Río Blanco. Electrum (Au,Ag) grains are shown images (A-D). Au-Ag-Te and $\mathrm{Au}-\mathrm{Ag}-\mathrm{Hg}$ phases are shown in $(\mathbf{B})$. Images $(\mathbf{A}, \mathbf{C})$ were taken using the back-scattered electron (BSE) detector, while images (B,D) were taken using a secondary electron (SE) detector. (E) shows the EDS spectrum of the electrum grain shown in (A). Ccp: chalcopyrite, Bn: bornite, Qtz: quartz, AuAg: electrum, AuAgTe: possibly sylvanite or petzite.

\section{Discussion}

Anomalous PGE contents were previously reported in $\mathrm{Cu}-\mathrm{Fe}$ sulfides and flotation concentrates from several porphyry $\mathrm{Cu}-\mathrm{Au}$ deposits [4], where high Pd contents (130-1900 ppb) are associated with high $\mathrm{Au}$ contents (1-28 ppm). Additionally, Pašava et al., 2010 [9] showed in the Kalmarkyr porphyry $\mathrm{Cu}-\mathrm{Au}-\mathrm{Mo}$ deposit in Uzbekistan average concentrations of $55 \mathrm{ppb} \mathrm{Pd}$, $5.5 \mathrm{ppb} \mathrm{Pt}$, and $4.1 \mathrm{ppm} \mathrm{Au}$ for disseminated and stockwork-type high-grade $\mathrm{Cu}-\mathrm{Au}-\mathrm{Mo}$ mineralization. Economou-Eliopoulos et al., 2000 [5] reported relatively high Pd contents in the Skouries PCD in Greece, ranging between 60 and 200 ppb (average 110 ppb). Furthermore, Economou-Eliopoulos 2005 [8] concluded that PGE-bearing porphyries have similar characteristics, 
including: (a) their association with alkaline or K-rich calc-alkaline systems; (b) the dominant occurrence of Pd-bearing minerals (merenskyite) within $\mathrm{Cu}$ sulfides, in association with $\mathrm{Au}-\mathrm{Ag}$ tellurides; and (c) the association of $\mathrm{Pd}, \mathrm{Pt}$, and $\mathrm{Au}$ with magnetite-bornite-chalcopyrite assemblages, within the pervasive potassic alteration zones in the central parts of the deposits.

The features described above are broadly similar to the occurrences of PGM in the Río Blanco $\mathrm{PCD}$, reported in this technical note. Our observations indicate that $\mathrm{Pd}, \mathrm{Pt}, \mathrm{Au}, \mathrm{Ag}$, and $\mathrm{Te}$ form micrometer to nanometer-sized mineral inclusions within chalcopyrite and bornite (Figures 2 and 3 ). PGM, Au, and Ag were found in early EBT veins characterized by quartz + chalcopyrite \pm bornite $\pm \mathrm{K}$ feldspar \pm anhydrite with biotite haloes, and in type- $\mathrm{A}$ veinlets with quartz $\pm \mathrm{K}$ feldspar \pm chalcopyrite, which are characteristic veins of the penetrative potassium feldspar alteration zone. Gold is found as electrum $(\mathrm{Au}, \mathrm{Ag})$, whereas the most common silver-bearing mineral is hessite, which was observed intergrown with merenskyite ( $\mathrm{PdTe}_{2}-\mathrm{Ag}_{2} \mathrm{Te}$ ). Importantly, Tarkian et al., 1999 [4] analyzed mineral concentrates from the major Chilean porphyry $\mathrm{Cu}-\mathrm{Mo}$ deposits (Río Blanco, Chuquicamata, Escondida, El Salvador and El Teniente). Among these, Río Blanco was the only deposit in which the authors did not report detectable concentrations of Pd and Pt. Since the aforementioned study focused on flotation concentrates, and no information was provided about the provenance of the samples within the deposit, it is likely that the apparent lack of Pd and Pt at Río Blanco was related to the fact that at the time, CODELCO was not mining the (deeper) potassic alteration zone, and the studied concentrate came from the upper portions of the deposit.

The mineralogical occurrence of Pd-bearing minerals (e.g., merenskyite, $\left((\mathrm{Pd}, \mathrm{Pt})(\mathrm{Bi}, \mathrm{Te})_{2}\right)$ at Río Blanco indicates that Pd was most likely introduced during the early potassic alteration stage from a high-temperature hydrothermal fluid. Xiong et al., 2000 [37] conducted a series of experiments on the solubility of Pd under hydrothermal conditions. High temperature, oxidized, and highly saline fluid conditions are thought to favor the hydrothermal transport of PGE. Xiong et al., 2000 [37] concluded that in the earlier stages of porphyry $\mathrm{Cu}-\mathrm{Mo}$ formation, fluids are fully capable of transporting at least $10 \mathrm{ppb}$ Pd. Recent experiments by Sullivan et al., 2018 [38] showed that Pd solubility increases with $f \mathrm{O}_{2}$, indicating that $\mathrm{Pd}$ is dissolved in the silicate melt at nickel + nickel oxide buffer (NNO) between 0 and +1 . Although the addition of $\mathrm{Cl}$ has a negligible effect on the solubility of $\mathrm{Pd}$, experimental studies have shown that $\mathrm{PdCl}_{4}{ }^{-2}$ predominates between 25 and $300{ }^{\circ} \mathrm{C}$. This complex is the main species at the $\mathrm{Cl}^{-}$concentrations observed in most hydrothermal fluids [39-41]. Since chloride ligands are generally invoked for $\mathrm{Cu}$ and $\mathrm{Au}$ transport in the porphyry environment [42,43], the close association of $\mathrm{Cu}$-sulfides and noble metal ( $\mathrm{Au}-\mathrm{Pd}-\mathrm{Ag}$ ) inclusions at Río Blanco may be explained, in part, by a similar transport and deposition mechanism as their host minerals. An alternative mechanism of PGE enrichment may involve Pd-Bi-Te phases, which may remain molten above $489{ }^{\circ} \mathrm{C}$ [44]. The aforementioned authors provide evidence of high $\mathrm{Pd}$ and $\mathrm{Bi}$ concentrations in brine inclusions from the Skouries PCD in Greece, suggesting that Bi-Te melts may act as a collectors for PGE in high temperature hydrothermal fluids.

\section{Concluding Remarks}

The occurrence of $\mathrm{Pd}, \mathrm{Pt}$, and Au-bearing minerals in copper sulfides at Río Blanco opens new avenues of research aimed at assessing the noble metal content of the deposit. Also, the presence of PGE-bearing minerals in the potassic alteration zone at Río Blanco PCD poses questions that are relevant to the understanding of the speciation and solubility of noble metals during mineralization and hydrothermal alteration. An equally important question is the quantity and intensity of the mineralizing (hydrothermal) events that contributed to the deposition of the noble metals in PCDs. These questions are closely linked because the deposition of precious metals during different hydrothermal events could result in different incorporation forms into sulfides, i.e., solid solution vs. micro or nano-inclusions. Therefore, further micro-analytical studies are needed to address these questions, and to evaluate the sulfide phases formed under different physical and chemical conditions as hosts of PGE and other critical metals in porphyry $\mathrm{Cu}-\mathrm{Mo}$ deposits. 
Author Contributions: J.C. collected the samples and studied the sulfides using SEM, FESEM, and EMPA. All authors (J.C., M.R., F.B., J.J.V. and C.M.) discussed the results and evaluated the data. J.C., M.R. and F.B. wrote and organized the paper. J.J.V and C.M. provided geological information and granted access to the mine and drillcore libraries.

Funding: The work was supported by the Iniciativa Científica Milenio, which provided funding through grant \#NC 130065 “Millennium Nucleus for Metal Tracing Along Subduction”. Additional support was provided by the Andean Geothermal Center of Excellence (CEGA), FONDAP project \#15090013. The Center for Research in Nanotechnology and Advanced Materials (CIEN) of the Pontifical Catholic University of Chile provided access to the FESEM used in this study, which was funded by FONDEQUIP Project EQM150101.

Acknowledgments: We thank the CODELCO Tech for providing a pre-doctoral Ph.D. scholarship to J. Crespo. The LAMARX Laboratory of the Universidad Nacional de Córdoba, Argentina, is acknowledged for granting access to the electron microprobe facility. This manuscript is dedicated to Romina, Naomi, and Tania.

Conflicts of Interest: The author declare no conflict of interest.

\section{References}

1. Johnson, K.M.; Hammarstrom, J.M.; Zientek, M.L.; Dicken, C.L. Estimate of Undiscovered Copper Resources of the World, 2013. USGS Fact Sheet 2014, 3004, 3. [CrossRef]

2. US Geological Survey 2018. Mineral Commodity Summaries; U.S. Geological Survey: Reston, VA, USA, 2018; 200p.

3. Einaudi, M.T.; Burt, D.M. A Special Issue Devoted to Skarn Deposits. Introduction-Terminology, Classification, and Composition of Skarn Deposits. Econ. Geol. 1982, 77, 745-754. [CrossRef]

4. Tarkian, M.; Stribrny, B. Platinum-group elements in porphyry copper deposits: A reconnaissance study. Miner. Petrol. 1999, 65, 161-183. [CrossRef]

5. Economou-Eliopoulos, M.; Eliopoulos, D.G. Palladium, platinum and gold concentration in porphyry copper systems of Greece and their genetic significance. Ore Geol. Rev. 1999, 16, 59-70. [CrossRef]

6. Simon, G.; Kesler, S.E.; Essene, E.J. Gold in Porphyry Copper Deposits: Experimental Determination of the Distribution of Gold in the Cu-Fe-S System at 400 to $700{ }^{\circ} \mathrm{C}$. Econ. Geol. 2000, 95, 259-270. [CrossRef]

7. Kesler, S.E.; Chryssoulis, S.L.; Simon, G. Gold in porphyry copper deposits: Its abundance and fate. Ore Geol. Rev. 2002, 21, 103-124. [CrossRef]

8. Economou-Eliopoulos, M. Platinum-group element potential of porphyry deposits. Min. Assoc. Can. Short Course 2005, 35, 203-245.

9. Pašava, J.; Vymazalova, A.; Kosler, J.; Koneev, R.; Jukov, A.V.; Khalmatov, R.A. Platinum-group elements in ores from the Kalmakyr porphyry $\mathrm{Cu}-\mathrm{Au}-\mathrm{Mo}$ deposit, Uzbekistan: Bulk geochemical and laser ablation ICP-MS data. Miner. Depos. 2010, 45, 411-418. [CrossRef]

10. McFall, K.A.; Roberts, S.; Teagle, D.; Naden, J.; Lusty, P.; Boyce, A. The origin and distribution of critical metals (Pd, Pt, Te and Se) within the Skouries Cu-Au porphyry deposit, Greece. Appl. Earth Sci. 2016, 125, 100-101. [CrossRef]

11. McFall, K.A.; Naden, J.; Roberts, S.; Baker, T.; Spratt, J.; McDonald, I. Platinum-group minerals in the Skouries $\mathrm{Cu}-\mathrm{Au}$ (Pd, Pt, Te) porphyry deposit. Ore Geol. Rev. 2018, 99, 344-364. [CrossRef]

12. U.S. Departament of Energy. Critical Materials Strategy, December 2011. Available online: https://www. energy.gov/sites/prod/files/DOE_CMS2011_FINAL_Full.pdf (accessed on 10 June 2018).

13. Geological Society of America. GSA Position Statement 2013 Critical Mineral and Materials. Available online: http:/ / www.geosociety.org/gsa/positions / position23.aspx (accessed on 20 June 2018).

14. Arndt, N.T.; Fontboté, L.; Hedenquist, J.W.; Kesler, S.E.; Thompson, J.F.H.; Wood, D.G. Future global mineral resources. Geochem. Perspect. 2017, 6, 1-171. [CrossRef]

15. Huston, D.L.; Sie, S.H.; Suter, G.F.; Cooke, D.R.; Both, R.A. Trace Elements in sulfide minerals from eastern australian volcanic-hosted massive sulfide deposits: Part I. proton microprobe analyses of pyrite, chalcopyrite, and sphalerite, and Part II. selenium levels in pyrite: Comparison with ( $834 \mathrm{~S}$ values and implications for the source of sulfer in volcanogenic hydrothermal system. Econ. Geol. 1995, 90, 1167-1196. [CrossRef]

16. Kesler, S.E.; Russell, N.; Mccurdy, K. Trace-metal content of the Pueblo Viejo precious-metal deposits and their relation to other high-sulfidation epithermal systems. Miner. Depos. 2003, 38, 668-682. [CrossRef] 
17. Large, R.R.; Danyushevsky, L.; Hollit, C.; Maslennikov, V.; Meffre, S.; Gilbert, S.; Bull, S.; Scott, R.; Emsbo, P.; Thomas, H.; et al. Gold and trace element zonation in pyrite using a laser imaging technique: Implications for the timing of gold in orogenic and carlin-style sediment-hosted deposits. Econ. Geol. 2009, 104, 635-668. [CrossRef]

18. Deditius, A.P.; Utsunomiya, S.; Reich, M.; Kesler, S.E.; Ewing, R.C.; Hough, R.; Walshe, J. Trace metal nanoparticles in pyrite. Ore Geol. Rev. 2011, 42, 32-46. [CrossRef]

19. Reich, M.; Deditius, A.; Chryssoulis, S.; Li, J.-W.; Ma, C.-Q.; Parada, M.A.; Barra, F.; Mittermayr, F. Pyrite as a record of hydrothermal fluid evolution in a porphyry copper system: A SIMS/EMPA trace element study. Geochim. Cosmochim. Acta 2013, 104, 42-62. [CrossRef]

20. Cioacă, M.E.; Munteanu, M.; Qi, L.; Costin, G. Trace element concentrations in porphyry copper deposits from Metaliferi Mountains, Romania: A reconnaissance study. Ore Geol. Rev. 2014, 63, 22-39. [CrossRef]

21. Franchini, M.; Mcfarlane, C.; Maydagán, L.; Reich, M.; Lentz, D.R.; Meinert, L.; Bouhier, V. Trace metals in pyrite and marcasite from the Agua Rica porphyry-high sulfidation epithermal deposit, Catamarca, Argentina: Textural features and metal zoning at the porphyry to epithermal transition. Ore Geol. Rev. 2015, 66, 366-387. [CrossRef]

22. Barra, F.; Deditius, A.; Reich, M.; Kilburn, M.; Guagliardo, P.; Roberts, M.P. Dissecting the Re-Os molybdenite geochronometer. Sci. Rep. 2017, 7, 16054. [CrossRef] [PubMed]

23. Zarasvandi, A.; Rezaei, M.; Raith, J.G.; Pourkaseb, H.; Asadi, S.; Saed, M.; Lentz, D.R. Metal endowment reflected in chemical composition of silicates and sulfides of mineralized porphyry copper systems, Urumieh-Dokhtar magmatic arc, Iran. Geochim. Cosmochim. Acta 2018, 223, 36-59. [CrossRef]

24. Singer, D.A.; Berger, V.I.; Moring, B.C. Porphyry Copper Deposits of the World: Database and Grade and Tonnage Models, 2008; U.S. Geological Survey: Reston, VA, USA, 2008. Available online: https:/ / pubs.usgs.gov/of/ 2008/1155/of2008-1155.pdf (accessed on 10 June 2018).

25. Sinclair, W.D. Porphyry deposits, in Goodfellow W, ed., Mineral Deposits of Canada: A synthesis of major deposit-types, district metallogeny, the evolution of geological provinces, and exploration methods. Geol. Assoc. Can. Miner. Depos. Div. 2007, 5, 223-243.

26. Reich, M.; Chryssoulis, S.L.; Deditius, A.; Palacios, C.; Zuniga, A.; Weldt, M.; Alvear, M. “Invisible” silver and gold in supergene digenite $\left(\mathrm{Cu}_{1.8} \mathrm{~S}\right)$. Geochim. Cosmochim. Acta 2010, 74, 6157-6173. [CrossRef]

27. Reich, M.; Palacios, C.; Barra, F.; Chryssoulis, S. "Invisible" silver in chalcopyrite and bornite from the Mantos Blancos Cu deposit, northern Chile. Eur. J. Mineral. 2013, 25, 453-460. [CrossRef]

28. Hanley, J.J.; MacKenzie, M. Incorporation of platinum-group elements and cobalt into subsidiary pyrite in alkalic $\mathrm{Cu}-\mathrm{Au}$ porphyry deposits: Significant implications for precious metal distribution in felsic magmatic-hydrothermal systems. In AGU Spring Meeting Abstracts; American Geophysical Union: Washington, DC, USA, 2009.

29. Ferraz, G.; Cruz, J. Inventario de Recursos Geológicos 2011, División Andina Superintendencia de Geología Gerencia de Recursos Mineros y Desarrollo; Informe Interno; CODELCO: Santiago, Chile, 2011.

30. Rivano, S.; Godoy, E.; Vergara, M.; Villaroel, R. Redefinición de la formacion farellones en la cordillera de los andes de chile central (32-34 S). Rev. Geol. Chile 1990, 17, 205-214.

31. Deckart, K.; Clark, A.H.; Aguilar, A.C.; Vargas, R.R.; Bertens, A.N.; Mortensen, J.K.; Fanning, M. Magmatic and hydrothermal chronology of the giant Río Blanco porphyry copper deposit, central Chile: Implications of an integrated U-Pb and ${ }^{40} \mathrm{Ar} /{ }^{39}$ Ar database. Econ. Geol. 2005, 100, 905-934. [CrossRef]

32. Thiele, R.; Cubillos, E. Hoja Santiago: Región Metropolitana: Carta Geológica de Chile Escala 1:250.000; Instituto de Investigaciones Geológicas: Santiago, Chile, 1980.

33. Stambuck, V.; Blondel, J.; Serrano, L. Geología del Yacimiento Río Blanco. Congr. Geol. Chileno Actas 1982, 2, 419-442.

34. Toro, J.C.; Ortúzar, J.; Zamorano, J.; Cuadra, P.; Juan, H.; Spröhnle, C. Protracted Magmatic-Hydrothermal History of the Río Blanco-Los Bronces District, Central Chile: Development of World's Greatest Known Concentration of Copper. Soc. Econ. Geol. Spec. Publ. 2012, 16, 105-126. [CrossRef]

35. Piquer, J.; Skarmeta, J.; Cooke, D.R. Structural Evolution of the Río Blanco-Los Bronces District, Andes of Central Chile: Controls on Stratigraphy, Magmatism, and Mineralization. Econ. Geol. 2012, 110, 1995-2023. [CrossRef]

36. Salinero, J. Eventos de Alteración y Mineralización en el Sector Río Blanco, Yacimiento Río Blanco, V Región, Chile. Bachelor's Thesis, Universidad de Chile, Santiago, Chile, 2004. 
37. Xiong, Y.; Wood, S.A. Experimental quantification of hydrothermal solubility of platinum-group elements with special reference to porphyry copper environments. Miner. Petrol. 2000, 68, 1-28. [CrossRef]

38. Sullivan, N.A.; Zajacz, Z.; Brenan, J.M. The solubility of Pd and Au in hydrous intermediate silicate melts: The effect of oxygen fugacity and the addition of $\mathrm{Cl}$ and S. Geochim. Cosmochim. Acta 2018, 231, 15-29. [CrossRef]

39. Hanley, J.J. The aqueous geochemistry of the platinum-group elements (PGE) in surficial, low-T Hydrothermal and High-T magmatic-hydrothermal environments. In Exploration for Platinum-Group Elements Deposits; Mungall, J.E., Ed.; Mineralogical Association of Canada: Québec, QC, Canada, 2005; Volume 35, pp. 35-56.

40. Gammons, C.H. Experimental investigations of the hydrothermal geochemistry of platinum and palladium: IV. The stoichiometry of $\mathrm{Pt}(\mathrm{IV})$ and $\mathrm{Pd}(\mathrm{II})$ chloride complexes at 100 to $300{ }^{\circ} \mathrm{C}$. Geochim. Cosmochim. Acta 1995, 59, 1655-1667. [CrossRef]

41. Gammons, C.H. Experimental investigations of the hydrothermal geochemistry of platinum and palladium: V. Equilibria between Pt metal, Pt(II) and Pt(IV) chloride complexes at 25 to $300^{\circ} \mathrm{C}$. Geochim. Cosmochim. Acta 1996, 60, 1683-1694. [CrossRef]

42. Sillitoe, R.H. Porphyry copper systems. Econ. Geol. 2010, 105, 3-41. [CrossRef]

43. Kouzmanov, K.; Pokrovski, G.S. Hydrotermal controls on metal distribution in Porphyry $\mathrm{Cu}(-\mathrm{Mo}-\mathrm{Au})$ Systems. Soc. Econ. Geol. Spec. Publ. 2012, 16, 573-618.

44. McFall, K.; Roberts, S.; Naden, J.; Wilkinson, C.; Wilkinson, J.; Boyce, A. Hydrothermal transport of PGEs in porphyry systems-A fluid history of the Skouries Cu-Au (PGE) porphyry deposit. Appl. Earth Sci. 2017, 126, 79-80. [CrossRef]

(C) 2018 by the authors. Licensee MDPI, Basel, Switzerland. This article is an open access article distributed under the terms and conditions of the Creative Commons Attribution (CC BY) license (http:/ / creativecommons.org/licenses/by/4.0/). 